YEARBOOK

of ANTITRUST

and REGULATORY

STUDIES

www.yars.wz.uw.edu.pl
Peer-reviewed scientific periodical, focusing on legal and economic issues of antitrust and regulation. Creative Commons Attribution-No Derivative Works 3.0 Poland License.

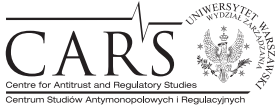

Centre for Antitrust and Regulatory Studies, University of Warsaw, Faculty of Management www.cars.wZ.uw.edu.pl

\title{
Key Legislative and Jurisprudential Developments of Polish Antitrust Law in 2011
}

\author{
by
}

Agata Jurkowska-Gomułka*

\section{CONTENTS}

I. Antitrust legislation

1. Competition Act amendment

2. Renewal of group exemption regulations

2.1. Group exemption for horizontal co-operation in the insurance sector

2.2. Group exemption for vertical agreements

2.3. Group exemption for specialisation and $R \& D$ agreements

3. Guidelines of the UOKiK President on the criteria and procedures concerning a notification of a concentration

II. Antitrust jurisprudence

1. General characteristics of 2011 jurisprudence

2. Entities organizing public utility services and antitrust violations

3. Identification of a relevant geographical market

4. Agreements restricting competition

4.1. Circumstances (not) excluding liability for anticompetitive agreements

4.2. Price agreements

4.3. Bid-rigging

5. Abuse of a dominant position

5.1. Imposition of unfair prices and trading conditions

5.2. Imposition of onerous terms and conditions

6. Control of concentration

6.1. Exceptional clearances concentration

* Dr. Agata Jurkowska-Gomułka, Department of European Economic Law, Faculty of Management, University of Warsaw; Scientific Secretary of the Centre for Antitrust and Regulatory Studies. 
6.2. Non-fulfilment of conditions imposed in a conditional merger clearance

7. Fines

8. Status of files of antitrust proceedings (administrative proceeding) before a competition court

9. Assessment of the UOKiK President' activities by administrative courts

10. Application of Article 5 of Regulation $1 / 2003$ by a national competition authority

\section{Abstract}

The article presents key developments in Polish antitrust legislation and jurisprudence of 2011. Its legislative part focuses on the renewal of Polish Group Exemption Regulations for vertical agreements, specialization and $R \& D$ agreements as well as cooperation agreements in the insurance sector. Noted is also the sole amendment of the Competition Act introduced in 2011 which concerns the financial liability of the Polish competition authority. The article covers also the new Guidelines of the UOKiK President on the criteria and procedures of merger notifications. Presented in its jurisprudential part is a number of 2011 rulings, mainly those rendered by the Supreme Court and the Court of Appeals, divided according to their subject matter with respect to particular types of restrictive practices and other problems related to the decision-making process of the UOKiK President.

\section{Résumé}

Cet article présente les développements principaux relatifs à la législation et jurisprudence antitrust polonaise en 2011. La partie législative de l'article se concentre sur le renouvellement de la réglementation portant sur l'exemption collectif des accords verticaux, ceux relatifs à la spécialisation et $\mathrm{R} \& \mathrm{D}$, ainsi que les accords de coopération dans le secteur des assurances. De plus, l'article mentionne un seul amendement à la Loi sur la concurrence. Les directives délivrées par le Président du Bureau de la concurrence et protection des consommateurs (UOKiK) en Pologne sur des critères et des procédures relatives à la notification d'une concentration à une autorité nationale de la concurrence sont y également brièvement décrites. Dans la partie sur la jurisprudence, l'article présente les décisions, surtout celles de la Cour suprême et de la Cour d'appel, qui sont divisées selon leur objet en faisant référence à des types particuliers de pratiques restrictives et d'autres problèmes liés au processus de la prise de décision par le Président de l'UOKiK.

Classifications and key words: abuse of a dominant position; anticompetitive agreements; antitrust case law; antitrust legislation; bid-rigging; common competition rule of the EU; group exemption; fines; Regulation 1/2003; relevant market; resale price maintanance; R\&D agreement; specialisation agreement. 


\section{Antitrust legislation}

\section{Competition Act amendment}

The Act of 16 February 2007 on Competition and Consumer Protection (hereafter, Competition Act ${ }^{1}$ ) was changed only once in 2011. The amendment was introduced by Article 15 of the Act of 20 January 2011 on Financial Liability of Public Servants for Manifest Law Violations ${ }^{2}$. On this basis, Article 81(3) of the Competition Act was supplemented by an additional provision imposing upon the UOKiK President a duty to determine, while annulling or amending his/her own decision, if the original decision was in fact adopted without a legal basis at all or with a manifest infringement of the law. A final determination of that type constitutes according to Article 6(10) of the Public Servants Liability Act, a manifest law violation within the meaning of this Act.

\section{Renewal of group exemption regulations}

\subsection{Group exemption for horizontal co-operation in the insurance sector}

The most significant legislative initiatives of 2011 in Polish antitrust are to be found in three regulations issued by the Council of Ministers that establish new group exemptions for certain categories of anticompetitive agreements. Based on Article 8(3) of the Competition Act, they replaced their respective predecessors issued in 2007. This way, the Council of Ministers responded in affirmative to doctrinal voices arguing in favour of adopting new Polish group exemptions rather than replacing national legislation by EU regulations ${ }^{3}$. Domestic group exemptions apply to agreements having an impact solely on the Polish market; EU regulations apply to co-operation affecting intra-EU trade. However, the new Polish acts are somewhat inspired by EU law. In comparison to their 2007 predecessors, the detailed conditions for exemption and the categories of exempted agreements covered by the regulations remained unchanged (vertical agreements, $R \& D$ and specialisation agreements, horizontal agreements in the insurance sector) albeit amendments were made to the scope of some of these categories.

\footnotetext{
1 Journal of Laws 2007 No. 50, item 331, as amended.

2 Journal of Laws 2011 No. 34, item 173.

3 See G. Materna, 'Wpływ prawa UE na polskie wyłączenia grupowe spod zakazu porozumień ograniczających konkurencję' ['The impact of EU law on Polish block exemption from the prohibition of agreements restricting competition'] (2010) 5 Europejski Przeglad Sadowy.
} 
Issued first was the Council of Ministers' Regulation of 22 March 2011 on the exemption of certain categories of agreements concluded by undertakings in the insurance sector from the prohibition of competition restricting agreements ${ }^{4}$ (hereafter, the Insurance Regulation). The new regulation replaced the Council of Minister's Regulation of 30 July $2007^{5}$ in force till 31 March $2011^{6}$. Commission Regulation (EC) of 24 March 2010 on the application of Article 101(3) of the Treaty to certain categories of agreements, decisions and concerted practices in the insurance sector ${ }^{7}$ acted as a reference point for the new Polish block exemption. Following the EU pattern, the national act decided to cut down the number of exempted fields of cooperation from six to just three. The current Polish group exemption applies therefore only to horizontal co-operation in: 1) joint compilation and distribution of information necessary for the calculation of average costs of specified risk coverage or the creation of mortality tables, etc $^{8}$.; 2) joint research on the probable impact of general circumstances, external to the interested undertakings, either on the frequency or on the scale of future claims for a given risk and the distribution of such studies ${ }^{9}$; 3 ) common coverage of certain types of risks (insurance pools) ${ }^{10}$. Co-operation in the compilation of information and research activities is eligible for exemption regardless of quantitative conditions. The block exemption for insurance pools created in order to cover new risks is time-limited to three years only but it is not dependent on market thresholds. Pools created for other types of risks can benefit from the block exemption if a market threshold of $20 \%$ for co-insurance groups and $25 \%$ for co-reinsurance is observed. The Insurance Regulation will expire on 31 March 2018 (a year after the corresponding EU act).

\subsection{Group exemption for vertical agreements}

A few days after the issuance of the Insurance Regulation, the Council of Ministers adopted anther act: Regulation of 30 March 2011 on the exemption of certain categories of vertical agreements from the prohibition of competition

4 Journal of Laws 2011 No. 67, item 355.

5 Council of Ministers' Regulation of 22 March 2011 on the exemption of certain categories of agreements concluded by undertakings in insurance sector from the prohibition of competition restricting agreements (Journal of Laws 2007 No. 137, poz. 964).

6 See J. Orlicka, 'Wyłączenie grupowe dla porozumień standardowych warunków ubezpieczenia - stan obecny i postulaty de lege ferenda' ['Block exemption for agreements on standard insurance contracts - a current state and de lege ferenda proposals'] (2010) 2(9) Rozprawy Ubezpieczeniowe.

7 OJ [2010] L 83/1.

8 See para. 3(1) and paras. 4 and 6 of the Insurance Regulation.

9 See para. 3(2) and paras. 5 and 6 of the Insurance Regulation.

10 See para. 3(3) and paras. 8-14 of the Insurance Regulation. 
restricting agreements ${ }^{11}$ (hereafter, the Vertical Agreements Regulation). Starting from 1 June 2011, the new act replaced its predecessor of the same name issued on 19 November $2007^{12}$. The Polish legislator directly admitted in a document explaining its reasons for adopting a new national block exemption that the 2001 act follows Commission Regulation (EU) No 330/2010 of 20 April 2010 on the application of Article 101(3) [TFEU] to categories of vertical agreements and concerted practices ${ }^{13}$. The Council of Ministers stated that reference to EU law guarantees transparency - undertakings potentially interested in using the block exemptions do not have to adapt their agreements to different sets of exempting conditions. Another reason was associated with the fact that market conditions in Poland do not differ greatly from those found in other Member States and the EU as a whole.

The scope of the Polish Vertical Agreements Regulation is based on Regulation 330/2010 and thus it presumes only one type of quantitative conditions for a 'standard' exemption - a market share threshold (the situation changes for vertical agreements between associations of undertakings or between undertakings being members of associations). The market share threshold of $30 \%$, either for a supplier or a buyer, remains the same in both the Polish and the EU block exemption ${ }^{14}$. If an agreement covers many parties each operating on a different level of the market, all of them have to fulfil the market share condition ${ }^{15}$. In comparison to its predecessor, the new act contains an amended definition of selective distribution ${ }^{16}$ and added a totally new legal definition of 'a customer of a buyer'17 (inspired by Regulation 330/2010 ${ }^{18}$ ). The 2011 block exemption introduced also detailed rules on exempting agreements between associations of undertakings and their members or between associations of undertakings and their suppliers ${ }^{19}$. Such practices were so far treated as 'normal' vertical agreements between 'independent' undertakings; now they benefit from the block exemption only if they fulfil additional conditions: all association members must be retailers of goods (not services) and the turnover of any of the members cannot exceed $50,000,000 \mathrm{EUR}^{20}$. The list of hardcore restrictions (black-listed provisions) remained almost unchanged but the new provisions stipulate that a prohibition

11 Journal of Laws 2011 No. 81, item 441.

12 Journal of Laws 2007 No. 230, item 1691.

13 OJ [2010] L 102/1.

${ }^{14}$ See para. 8(1) of Vertical Agreements Regulation.

15 See para. 8(2) of Vertical Agreements Regulation.

16 See para. 3(5) of Vertical Agreements Regulation.

17 See para. 3(15) of Vertical Agreements Regulation.

18 See Article 1(1)(i) of Regulation 330/2010.

19 See para. 5 of Vertical Agreements Regulation.

20 See Article 3(2) and 2(2) of Regulation 330/2010. 
of sales of goods to distributors outside the selective distribution system on a territory where a supplier operates in a selective distribution system does not constitute a black-listed clause ${ }^{21}$. The Vertical Agreements Regulation will stay in force till 31 May 2023.

\subsection{Group exemption for specialisation and R\&D agreements}

The last block exemption issued in 2011 was the Council of Ministers' Regulation of 13 December 2011 on the exemption of specialisation agreements and research and development agreements from the prohibition of competition restricting agreements ${ }^{22}$ (hereafter, the Horizontal Agreements Regulation). The new act replaced the identically named block exemption of 19 November $2007^{23}$. Issuing a single regulation covering both categories of horizontal co-operation, regulated in the EU by two separate acts, is a type of Polish legislative tradition. Still, the detailed provisions of the new Polish block exemption are patterned on the two existing EU acts: Commission Regulation (EU) No. 1217/2010 of 14 December 2010 on the application of Article 101(3) [TFEU] to certain categories of research and development agreements ${ }^{24}$ and Commission Regulation (EU) No. 1218/2010 of 14 December 2010 on the application of Article 101(3) [TFEU] to certain categories of specialisation agreements ${ }^{25}$. The key change introduced into the new Polish block exemption is the broadened scope of exemption provided for R\&D agreements which now covers, aside from joint research and development, joint exploitation of $\mathrm{R} \& \mathrm{D}$ research and a combination thereof, as well as the so called 'paid-for research and development' and 'joint exploitation of results from paid-for research and development ${ }^{26}$. The latter type of $\mathrm{R} \& \mathrm{D}$ cooperation refers to a situation where only one party conducts the actual R\&D activities while the other party finances it. In comparison to its predecessor, the new Polish Regulation introduced a number of new legal definition: 'paid-for research and development'27, 'financing party'28, 'common distribution'29, 'specialisation in research and development' ${ }^{30}$, 'specialisation in exploitation of $\mathrm{R} \& \mathrm{D}$ results ${ }^{\prime 31}$

21 See para. 11(2)(d) of Vertical Agreements Regulation.

22 Journal of Laws 2011 No. 288, item 1691.

23 Journal of Laws 2007 No. 230, item 1962.

24 OJ [2010] L 335/36.

25 OJ [2010] L 335/43.

26 See para. 3(1)(2)(d-f) of Horizontal Agreements Regulation.

27 See para. 2(7) of Horizontal Agreements Regulation.

28 See para. 2(8) of Horizontal Agreements Regulation.

29 See para. 2(10) of Horizontal Agreements Regulation.

30 See para. 2(12) of Horizontal Agreements Regulation.

31 See para. 2(13) of Horizontal Agreements Regulation. 
and 'goods of a downstream market' 32 . The latter is useful when goods covered by a specialisation agreement are used as input for the manufacturing of goods on a downstream market by one or more parties to the specialisation agreement. Market share thresholds as a condition for the application of the block exemption were left unchanged but the rules on measuring market shares of the parties seem more precise now ${ }^{33}$.

Unlike the 2007 regulation, certain clauses that used to be considered admissible in horizontal co-operation agreements were modified, mainly in order to make them clearer ${ }^{34}$. The list of hard-core restrictions (black-listed clauses) in specialisation agreements was not changed but the list of prohibited clauses in R\&D agreements was substantially amended. For instance, the 2011 Regulation specifies that the prohibition of using a clause on resale price fixing of goods extends also over the prices of the licensing processes. The new Horizontal Agreements Regulation broadens one of the conditions for joint exploitation of $R \& D$ results whereby parties to $R \& D$ agreement are now allowed to require compensation for giving access to $R \& D$ results in order to continue research or to exploit its results; compensation cannot, however, be excessive so as to limit or impede access to $R \& D$ results ${ }^{35}$. The new exemption entered into force on 1 January 2012 and will be valid till 31 December 2023.

All of the new regulations contain provisions making it possible for undertakings to adapt their existing agreements to the new conditions (if any) established in the acts of 2011 in order to maintain the benefit of block exemptions granted under the acts adopted in 2007.

\section{Guidelines of the UOKiK President on criteria and procedures concerning a notification of a concentration}

Guidelines issued by the UOKiK President are not a source of binding law but the fact that they are published in the UOKiK Official Journal ${ }^{36}$ make them, to a certain extent, binding for the UOKiK President himself/herself (as it is stated in their introduction that 'the UOKiK President applies them'). The objective of the Guidelines is enhancing legal certainty for undertakings regarding the duty to notify an intention to concentrate as well as other issues connected with antitrust proceedings in merger cases. The Guidelines cannot

32 See para. 2(14) of Horizontal Agreements Regulation.

33 See para. 4 of Horizontal Agreements Regulation.

34 See para. 3(2) of Horizontal Agreements Regulation.

35 See para. 9(1)(c) and 9(2) of Horizontal Agreements Regulation; Article 3(2) of Regulation $1217 / 2010$.

${ }^{36}$ UOKiK Official Journal 2011 No. 1, item 1. 
regulate concentration-related problems in a way contrary to the provisions of the Competition Act; they only explain how the UOKiK President assesses selected problems associated with merger control. The document is divided into three parts: 1) criteria of notification of an intention to concentrate, 2) notification procedure, 3 ) sanctions for failure to fulfil the notification duty and violating other concentration-related provisions.

\section{Antitrust jurisprudence}

\section{General characteristics of 2011 jurisprudence}

This review covers selected judgments delivered in 2011 by three Polish courts engaged in antitrust cases: the Supreme Court (in Polish: Sad Najwyższ; hereafter, SN), the Court of Appeals in Warsaw (in Polish: Sad Apelacyjny $w$ Warszawie; hereafter, SA) and the Court of Competition and Consumer Protection (in Polish: Sąd Ochrony Konkurencji i Konsumentów; hereafter, SOKiK). According to last year's UOKiK Activity Report ${ }^{37}$, SOKiK delivered 58 rulings in antitrust cases in 2011; the Court of Appeals rendered 30 judgments and the Supreme Court only $3^{38}$.

All the judgments subject to this analysis are based on the Competition Act, mainly the Competition Act of 2007 which is currently in force. Some of the rulings refer also to practices that infringed, or at least had been declared to have done so, the provisions of the earlier Competition Act of $2000^{39}$ (cases resulting from an earlier intervention by the higher instance courts). The article focuses on rulings delivered by the Supreme Court and the Court of Appeals; SOKiK's first instance judgments are covered to a lesser degree since they can find themselves subject to further juridical revision, especially if they concern controversial issues.

No general database exists for Polish jurisprudence that would make it possible to identify all judgments delivered in any given timeframe by a particular court. As a result, the choice of rulings assessed here was made on the basis of the resources collected by CARS.

37 The Report is available in English at: http://www.uokik.gov.pl/reports_on_activities.php.

38 The data shows an increase in the activities of the Court of Appeals and SOKiK in comparison to 2010 - see A. Piszcz, 'Przegląd polskiego orzecznictwa antymonopolowego za lata 2010-2011 (cz. II)' ['Review of Polish antitrust case law in 2010-2011'] (2012) 3(1) iKAR 67.

39 Act of 15 December 2000 on Competition and Consumer Protection (Journal of Laws 2000 No. 122, item 1319, as amended). 
Not unlike in previous years, the jurisprudence of 2011 shows a clear predominance of cases dedicated to competition restricting practices - most of all, cases concerning the abuse of dominance. Abuses assessed by courts took the form of (or were alleged to have taken the form of): imposition of unfair prices (e.g. SA judgment of 29 April 2011, VI Aca 1171/10, ZWiKw Strzelinie; SA judgment of 31 May 2011, VI Aca 1028/10, STALEXPORT; SOKiK judgment of 3 October 2011, XVII Ama 4/10, PKS w Elblagu; SOKiK judgment of 11 March 2011, XVII Ama 56/10, Marquard Media; SOKiK judgment of 22 December 2011, XVII Ama 65/10, PGK EKOM); limiting production, sale or technological progress (SOKiK judgment of 17 March 2011, XVII Ama 227/09, Galicjanka)); imposition of onerous contractual terms yielding unjustified profits to the dominant undertaking (e.g. SN judgment of 5 May 2011, III SK 36/10, ENION; SA judgment of 7 June 2011, VI Aca 415/11, ENION; SA judgment of 15 July 2011, VI Aca 1301/10, Dolnoślaska Spótka Gazownictwa); discriminatory practices (e.g. SOKiK judgment of 27 September 2011, XVII 35/10, Sped-Pro); counteracting the formation of conditions necessary for the emergence or development of competition (e.g. SA judgment of 26 May 2011, VI Aca 1081/10, Rychwal Commune; SA judgment of 14 April 2011, VI Aca 1084/10, Przedsiębiorstwo Ustug Komunalnych in Grajewo; SOKiK judgment of 13 April 2011, XVII Ama 223/09, Przedsiębiorstwo Ustug Komunalnych w Olszynie; SOKiK judgment of 14 September 2011, XVII Ama 2/10, Celowy Zwiazek Gmin; SOKiK judgment of 11 April 2011, XVII Ama 62/08, Telekomunikacja Polska; SOKiK judgment of 11 April 2011, XVII Ama 123/09, FAMIS; SOKiK judgment of 17 February 2011, XVII Ama 231/10, PZU); tying (SA judgment of 29 March 2011, VI Aca 1087/10, Krajowa Stacja Chemiczno-Rolnicza; SA judgment of 21 July 2011, VI Aca 1303/10, RPWiK w Tychach); market sharing (e.g. SOKiK judgment of 31 March 2011, XVII Ama 19/10, Horbaczewski; SOKiK judgment of 13 April 2011, XVII Ama 223/09, Przedsiębiorstwo Ustug Komunalnych w Olszynie).

The majority of the scrutinised abuses took place on local, often municipal, markets including: a local market for streets, squares and public roads lightening services on the territory of the Bochnia Commune (SN judgment of 5 May 2011, III SK 36/10, ENION; SA judgment of 7 June 2011, VI Aca 415/11, ENION); a local market of liquid waste collection and transport (SA judgment of 26 May 2011, VI Aca 1081/10, Rychwal Commune; SOKiK judgment of 11 April 2011, XVII Ama 123/09, FAMIS); a local market for waste transport (SA judgment of 14 April 2011, VI Aca 1084/10, Przedsiębiorstwo Ustug Komunalnych in Grajewo); a local market for the provision of water and/or sewage collection (e.g. SA judgment of 29 April 2011, VI Aca 1171/10, ZWiKw Strzelinie; SA judgment of 21 July 2011, VI Aca 1303/10, RPWiK w Tychach; SOKiK judgment of 22 December 2011, XVII Ama 65/10, PGK EKOM); a local market for cemeteries 
and funeral services (SOKiK judgment of 13 April 2011, XVII Ama 223/09, Przedsiębiorstwo Ustug Komunalnych $w$ Olszynie); a local market for bus transport services (SOKiK judgment of 3 October 2011, XVII Ama 4/10, PKS $w$ Elblagu); a local market for waste management (SOKiK judgment of 30 June 2011, XVII Ama 24/08, MPO w Krakowie); a local market for cable television and products connected to the provision of cable television services (SOKiK judgment of 31 March 2011, XVII Ama 127/08, Toya); a local market for timber sales (SOKiK judgment of 31 March 2011, XVII Ama 19/10, Horbaczewski); a local market of paid access to the A-4 Katowice-Kraków motorway (SA judgment of 31 May 2011, VI Aca 1028/10, STALEXPORT); a local market for the administrating and executing of a concession for the exploitation of mineral water from a certain spring (SOKiK judgment of 17 March 2011, XVII Ama $227 / 09$, Galicjanka). Some relevant markets covering a territory of more than one commune were not seen as 'local' but as 'regional': a regional market for gas distribution (SA judgment of 15 July 2011, VI Aca 1301/10, Dolnoślaska Spótka Gazownictwa), a regional market for waste storage (SOKiK judgment of 14 September 2011, XVII Ama 2/10, Celowy Zwiazek Gmin).

A few abuse cases, mainly those assessed by the Supreme Court, concerned practices employed on national markets such as: a market for chemical soil analysis (SA judgment of 24 May 2011, VI Aca 1334/10, Przybysz-Kosiady); a market for rail transport of goods (e.g. SOKiK judgment of 27 September 2011, XVII 35/10, Sped-Pro; SOKiK judgment of 18 April 2011, XVII Ama 155/09, PKP Cargo); a market for sport newspapers sales (SOKiK judgment of 11 March 2011, XVII Ama 56/10, Marqurd Media); a market for the provision of services of Internet access to final users connected to public telecoms networks (SOKiK judgment of 11 April 2011, XVII Ama 62/08, Telekomunikacja Polska); a market for the organization of the provision of healthcare services financed from public funds (SOKiK judgment of 20 April 2011, XVII Ama 201/09, NFZ); a market for collective life insurance for employees (SOKiK judgment of 17 February 2011, XVII Ama 231/10, PZU).

Most of the multilateral practices subject to juridical review in 2011 were price-related (SN judgment of 3 November 2011, III SK 21/11, Röben; SA judgment of 20 July 2011, VI ACa 141/11, Chemik J.D. Krieger; SOKiK judgment of 8 June 2011, XVII Ama 23/09, ZAIKS, SFP; SOKiK judgment of 18 January 2011, XVII Ama 25/10, Budmex; SOKiK judgment of 27 April 2011, XVII Ama 44/09, Castorama; SOKiK judgment of 28 April 2011, XVII Ama 133/09, Hajduki and other judgments related to this agreement; SOKiK judgment of 18 July 2011, XVII Ama 167/09, ACS Sluchmed). One practice ruled on by SOKiK concerned an agreement on the terms of sales of goods - a prohibition to resell by distributors goods purchased from a certain supplier (SOKiK judgment of 4 April 2011, XVII Ama 100/09, AKPOL). One of the judgments 
concerned bid rigging (SA judgment of 8 April 2011, VI ACa 1071/10, Miejskie Przedsiębiorstwo Zieleni w Lublinie).

Competition restricting agreements were scrutinised mainly with respect to national markets such as: a market for the wholesale of chemical construction materials (SA judgment of 20 July 2011, VI Aca 141/11, Chemik J.D. Kreisel); a market for the sale of audiovisual works on physical carriers designed for personal use and a market for collective management of copyright for audiovisual works (SOKiK judgment of 8 June 2011, XVII Ama 23/09, ZAIKS, $S F P$ ); a market for the distribution of drainpipes (SOKiK judgment of 18 January 2011, XVII Ama 25/10, Budmex); a market for the wholesale of paints and lacquers (e.g. SOKiK judgment of 27 April 2011, XVII Ama 44/09, Castorama; SOKiK judgment of 28 April 2011, XVII Ama 133/09, Hajduki); a market for the sale of children goods (SOKiK judgment of 4 April 2011, XVII Ama 100/09, AKPOL); a market for sales of hearing aids (e.g. SOKiK judgment of 18 July 2011, XVII Ama 167/09, ACS Sluchmed). Only few of the reviewed agreements related to local markets such as the market for maintenance services of municipal greeneries in Lublin (SA judgment of 8 April 2011, VI ACa 1071/10, Miejskie Przedsiębiorstwo Zieleni w Lublinie)

Two judgments were adopted as appeals against decisions issued by the UOKiK President banning a concentration but both of the prohibitive decisions were sustained. One of these concerned battery recycling (SOKiK judgment of 13 April 2011, XVII Ama 78/09, Orzet Biaty) and the other related to the production of railway infrastructure (SOKiK judgment of 5 April 2011, XVII Ama 213/09, Cogifer). Another merger-related judgment focused on the imposition of fines for the non-fulfilment of obligations (obligation to dispose of rights to some assets) imposed on the acquiring company (Carrefour) in a conditional clearance of a concentration (3 October 2011, XVII Ama 8/10, Carrefour).

\section{Entities organizing public utility services and antitrust violations}

In a judgement of 24 May 2011, VI Aca 1334/10, Przybysz-Kosiady, the Court of Appeals expressed the opinion that entities organizing public utility services were subject to the Competition Act if due to the nature of their activity they could be qualified as an entity participating in the market and conducting an economic activity. However, State's imperious activity is not an economic activity and thus not subject to competition law. Distinguishing a business (entrepreneurial) activity from an activity within public imperium is justified mainly in the context of the interpretation of Article 4(1)(a) of the Competition Act (containing a legal definition of the term 'undertaking'). According to the Court, objectives of the Competition Act do not provide for 
an assessment of competition law compliance of imperious activity of entities exercising public powers. As a result, if it is the legislator that determines the prices of certain services, rather than an entity fulfilling State policy tasks (e.g. conducting a chemical soil analysis), and the latter only applies such imposed prices, its activity cannot be assessed under the Competition Act.

\section{Identification of a relevant geographical market}

In a judgment of 31 May 2011, VI Aca 1028/10, STALEXPORT, the Court of Appeals sustained SOKiK's view that a relevant geographical market could be described as a market for paid access to a specific part of the KrakowKatowice A-4 motorway. The Court noted a rule formulated by the European Commission that a relevant geographical market covers the territory where the undertakings concerned actually conduct their business. The Court of Appeals shared the jurisprudential view that a market defined in abuse proceedings could be very narrow, especially when the imposition of unfair prices for an individual product on an individual local market was alleged. The features of motorways make it so that other roads in the same area or equivalent rail connections cannot be considered as substitutes. The fact that in a concession contract other roads on the same territory were called 'competitive' cannot be binding as even parties admitted that in order to ensure the competitiveness of their roads with the motorway, it was necessary to increase their standard.

\section{Agreements restricting competition}

\subsection{Circumstances (not) excluding liability for anticompetitive agreements}

In a judgment of 20 July 2011, VI Aca 141/11, Chemik J.D. Kreisel, the Court of Appeals commented on arguments recalled by parties to a vertical agreement on minimal prices in order to justify their participation in a prohibited practice and to be declared 'innocent' of a violation of Article 6(1) of the Competition Act. The Court claimed that the sole fact of an economic dependence from a contractor was not enough to exclude the illegality of the activities of the parties to the scrutinised agreement. Accordingly, economic dependence of one party from the other can limit its freedom to act but does not eliminate it. The fact that a party was coerced to conclude an illegal agreement by another party, which used its leading market position to do so, cannot be considered as a 'mitigating factor' for the former because the 'weaker' party could have reported such a situation to the competition authority. Lack of awareness of the illegality of a practice does not eliminate 
liability for competition law violations. The Court of Appeals claimed: 'Acting in good faith and a conviction that an agreement does not infringe the law (...) is not enough to exclude the illegality of a practice'. The Court continued to say that undertakings often assume that a passive role in an illegal agreement eliminates their liability for the practice. Such circumstances can, however, only be analyzed in the context of fine setting. In the Court's view, liability is excluded only by an active attitude of rejection of the practice (open objection to the participation in an illegal agreement, leaving no doubts as to the lack of intention to engage in an illegal practice).

\subsection{Price agreements}

The most important judgment of 2011 on price agreements was the ruling delivered by the Supreme Court on 23 November 2011, III SK 21/11, Röben. The Court presented therein a new approach to vertical agreements on resale price maintenance (hereafter, RPM). Such agreements used to be treated by Polish jurisprudence (and often also in Polish literature) as prohibited per se. The Supreme Court did not share this position, however, and claimed that RPM might be pro-competitive and as such, it could be subject to a legal exemption from the overall prohibition of competition restricting agreements. According to the Court, RPM may be pro-competitive if it allows a manufacturer (but not a distributor) to enter a new market, if it prevents free-riding and if it supports a short-term campaign of low prices in order to build a coherent vision of a sale network. The Röben ruling is said to be inspired by the Leegin judgment of the US Supreme Court ${ }^{40}$ and may be treated as an announcement of a shift in Polish jurisprudence on RPM.

However, in a judgment delivered on 20 July 2011, VI Aca 141/11, Chemik J.D. Kreisel, and thus proceedings the Röben ruling, the Court of Appeals confirmed a strictly prohibited nature of vertical agreements on minimal prices. The Court even said that such agreements are per se prohibited and there was no need to calculate the market share of their participants. The judgment could be treated as proof that the Polish juridical line on vertical price agreements is still conservative, but this opinion is not true in the context of two other judgments. First, in a judgment of 18 January 2011, XVII Ama 25/10, Budmex, SOKiK annulled a decision of the UOKiK President on a prohibited vertical price agreement because of lacking evidence for the

40 A. Bolecki, 'Ustalanie minimalnych cen odsprzedaży - czas na zmiany. Glosa do wyroku Sądu Najwyższego z dnia 23.11.2011 r. w sprawie III SK 21/11 (Röben Ceramika Budowlana)' ['Resale price maintenance - time for changes. Case comment to the judgment of the Supreme Court of 23 November 2011 in case III SK 21/11 (Röben Ceramika Budowlana)'] (2012) 3(1) iKAR 107. 
anticompetitive effects of the agreement. The second ruling showing a more flexible approach to vertical price agreements was delivered by the Court of Appeals on 21 September 2011, VI Aca 240/11. It was stated therein that the sole fact of signing a distribution contract could not be treated as equal to the participation in an anticompetitive agreement. An existence of a price agreement should be proven without a doubt by various evidential sources and not only by submitting a copy of the contract. The Court stipulated in its verdict that the UOKiK President failed to propose any logical reasoning that would prove the existence of an anticompetitive agreement. The justification of the antitrust decision was based mainly on the statements of the undertaking that has in fact initiated the very proceedings.

Regarding price cartels, in a judgment in the ZAIKS/SPF case, SOKiK affirmed that an imposition of rigid prices is 'the hardest violation of competition law' (a judgment of 8 June 2011, XVII Ama 23/09, ZAIKS, SFP).

\subsection{Bid-rigging}

Bid-rigging is commonly seen as vary harmful for competition but rather difficult to discover ${ }^{41}$. It is worth mentioning the criteria for assessing this type of practice as pointed out by the Court of Appeals in a judgment delivered on 8 April 2011, VI Aca 1071/10 Miejskie Przedsiebiorstwo Zieleni w Lublinie. Accordingly, the fact that in a tender organized by a municipality four undertakings submitted non-colliding offers for maintenance services for city greeneries and that these offers exhausted around $98 \%$ of the tender's budget should be regarded as proof of bid-rigging. Contents of the offers show that tender participants decided on a territorial division (each of them submitted an offer for a different part of the city) in order to avoid competing with each other and simultaneously benefit from the entire available tender budget. The participants' arguments that their offers covered only the city district best known to them could not be approved as the same companies have submitted offers in earlier tenders for servicing multiple districts. The Court said that an offer covering only one city area is not economically sound as every rational tender participants would consider not only its knowledge of the area but also other factors such as transport costs, tender value and its overall resources. The fact that four separate offers nearly exhausted the entire tender budget confirmed that the participants were not afraid of submitting bids that would compete with others. The Court admitted, however, that all of these arguments would not have been a sufficient basis for an allegation of bid-rigging if not for

41 E. Wojtczak, 'Zwalczanie zmów przetargowych w Polsce' ['Counterfighting tender collusions in Poland'] (2010) 7 Państwo i Prawo. 
the fact that the competition authority has proven that the participants had communicated with each other very intensively before and during the tender.

\section{Abuse of a dominant position}

\subsection{Imposition of unfair prices and trading conditions}

In a judgment of 31 May 2011, VI Aca 1028/10, STALEXPORT, the Court of Appeals ruled on an antitrust case of high importance for the Polish public opinion. The second instance Court sustained a SOKiK judgment approving a decision of the UOKiK President which found that charging the maximum price provided for in a motorway access price list during the time of that motorway's reconstruction (which caused many traffic disturbances) constituted an abuse of a dominant position in the form of an imposition of unfair prices (a practice prohibited by Article 9(2)(1) of the Competition Act). The Court of Appeals confirmed that motorway access prices charged on the basis of a contract between a private company managing it and the Polish State cannot be treated as a 'public burden' (similar e.g. to taxes). Instead, it is a price that can be analysed in light of the abuse of dominance prohibition. In the Court's view, the reconstruction and modernization of a motorway results in a decrease of that road's overall standard which causes the motorway to lose its special features distinguishing it from other public roads. An exclusion of one lane or a speed restriction causes a motorway to fail in fulfilling its role properly and thus, it is not justified to impose upon its users access charges at the same level as in times of no disturbances. The Court of Appeals claimed that a 'full price' can be charged only if users benefit from 'full equivalence' of services ${ }^{42}$. If a motorway operator does not provide such equivalence, it is not entitled to charge full prices, especially because there is no alternative motorway to the one under construction (the scrutinised operator is the only service-provider available so it abused its dominant position by imposing unfair prices).

Unfair prices can also take, in the meaning of Article 9(2)(1) of the Competition Act, the form of excessive prices ${ }^{43}$. Acknowledging a certain price as 'excessive' does not have to be necessarily connected to profits actually gained by the dominant company. The Court of Appeals asserted that an excessive

42 On the problem of equivalence see $Ł$. Węgrzynowski, 'Ekwiwalentność świadczeń w orzecznictwie antymonopolowym' ['Equality of subjects of contracts in antitrust jurisprudence'] (2010) 4 Glosa.

43 See A. Brzezińska-Rawa, 'Nadużycie pozycji dominującej w postaci stosowania ceny nadmiernie wygórowanej' ['Abuse of a dominant position by applying excessive prices'] (2011) 1 Przeglad Prawa Publicznego.

VOL. 2012, 5(7) 
nature of a price was of importance mainly for customers obliged to pay such a price (judgment of 29 April 2011, VI Aca 1171/10, ZWiK $w$ Strzelinie). It is thus necessary to assess prices from the customers' perspective because they compare the prices they pay with those paid by customers in neighbouring communes. In the Court's view, if an undertaking applies very high prices and yet does not gain any profit from it, it means that the price has not been calculated properly and that the whole activity of that undertaking needs to be improved (lack of profit despite very high prices indicates an improper cost structure). The sole fact that the company at stake eliminated cross-subsidizing (which used to keep prices low) does not make it impossible to determine that the price at which the dominant undertaking arrived was in fact excessive and unfair.

\subsection{Imposition of onerous agreement terms and conditions}

In a judgment of 5 May 2011, III SK 36/10, ENION ${ }^{44}$, the Supreme Court restated that in light of its settled jurisprudence, 'unjustified profits' in the meaning of Article 8(2)(6) of the Competition Act 2000 (currently Article 9(2) (6) of the Competition Act) are 'profits that would have not been achieved by an undertaking on a competitive market' (SN judgment of 16 October 2008, III SK 2/08). At the same time, an 'onerous agreement term' is a term that 'constitutes for one party of an agreement a burden bigger than commonly accepted in a certain types of relationships ( $\mathrm{SN}$ judgment of 16 October 2008, III SK 8/08). The facts of the case at hand showed that prices charged by an energy company (ENION) for providing energy for street lights in the Bochnia Commune did not cover infrastructure exploitation costs. The Supreme Court claimed that ENION did not enjoy double profits for the same service when it demanded that the Commune covers maintenance services costs as well. In the Court's view, the Energy Law Act cannot be interpreted in a way that excludes the possibility of charging prices that reflect the costs of appliance maintenance, installation and networks used for street lighting. Simultaneously, there is no rule on a duty to cover such costs by an energy company. Even if paying such costs is burdensome for the Commune, it does not bring unjustified profits to the energy company. The Court stated that a rational undertaking, even one holding a dominant position, aims to achieve an income at least covering the costs of its functioning, including a minimal level of profits allowing for a reconstruction of assets.

In a judgment of 15 July 2011, VI Aca 1301/10, Dolnoślaska Spótka Gazownictwa, the Court of Appeals confirmed a doctrinal view that a contractual

${ }^{44}$ As a response to this judgment, the Court of Appeals in its ruling of 7 June 2011, VI Aca 415/11, changed the SOKiK judgment by stating that ENION did not violate the abuse prohibition. 
condition is onerous if it places on one of the parties a burden heavier than commonly accepted in relationships of a certain kind. Accordingly, what needs to be examined is if a dominant company would be able to negotiate a similar condition in a hypothetical situation of free competition. An onerous nature of a condition should however be scrutinized in the overall context of all provisions applied to a certain contract. The Court stressed that an exploitative character of a practice should be examined with reference to the content of the 'imposed' contract, not its execution.

\section{Control of concentration}

\subsection{Extraordinary consent for concentrations}

SOKiK ruled on 13 April 2011, XVII Ama 78/09, Orzet Biaty, on an appeal against a decision prohibiting a concentration issued by the UOKiK President. The Court expressed in this case its opinion on exceptional clearances for concentrations that can be issued in Poland on the basis of Article 20(2) of the Competition Act even if the notified operation was to result in a significant impediment of competition ${ }^{45}$. Accordingly, the legal provision on exceptional clearances is based on the rule of reason whereby some restraints of competition should be admissible if they bring about general economic or social benefits outweighing the operation's anticompetitive effects. The Court affirmed: 'The Competition Act should prevent only unreasonable restraints of market competition (also when the restraint is a result of a concentration). Such an assumption is related to the fact that the protection of competition is not the sole goal of the Competition Act [but rather] achieving certain benefits in a general socio-economic interest. If such benefits can also be achieved by restricting competition (also as a result of a concentration), activities leading to such restraints are not seen as prohibited by the Act'. All this notwithstanding, SOKiK did not approve of the benefits listed by the plaintiff in this case as reasons justifying the issue of an exceptional clearance (ecological safety of the State; interests of Polish science; improving the innovativeness of the economy; providing a workplaces for the employees of the undertakings concerned; avoiding insolvency of the recycling companies).

45 More on exceptional clearances of concentration in Polish antitrust law: M. Błachucki, R. Stankiewicz, 'Decyzja zezwalająca na dokonanie koncentracji z naruszeniem testu istotnego ograniczenia konkurencji (art. 20 ust. 2 ustawy antymonopolowej)' ['Decision of the competition authority clearing a merger which substantially impedes competition (Art. 20(2) of the Polish antimonopoly act)'] (2010) 6 Przeglad Ustawodawstwa Gospodarczego. 


\subsection{Non-fulfilment of conditions imposed in a conditional merger clearance}

In a judgment of 3 October 2011, XVII Ama 8/10, Carrefour, SOKiK assessed the justification given by Carrefour for its failure to fulfil the obligations imposed upon it in a conditional merger clearance.Carrefour was obliged to dispose of its rights (ownership rights, renting rights, usufruct, etc.) to a number of super- or hypermarkets in locations indicated by the UOKiK President. Carrefour's failure to fulfil these obligations in the specified timeframe resulted in a fine imposed by the UOKiK President. The Court sustained the decision of the antitrust authority claiming that the plaintiff did not prove that the fulfilment of the conditions was impossible if the company was to act with proper care. The Court even suggested that the company could have, if need be, disposed of its rights gratuitously. SOKiK stated that while accepting the obligations imposed in the conditional clearance, the company should have known that it would not find a buyer willing to pay a price that would satisfy Carrefour. As such, it must have considered the possibility that it would have to dispose of the specified rights even on a gratuitous basis. The Court claimed that before all the legal activities concerning the concentration were completed, the plaintiff has had the possibility to scrutinize the financial effects of the fulfilment of the conditions, and especially if the concentration would still be profitable if difficulties occurred in disposing the contested rights. According to SOKiK, the company should have anticipated circumstances such as falling attractiveness of the real estate on sale (resulting from the appearance of competitive buildings) or a general collapse of demand. As a result, such circumstances could not justify the failure to fulfil the said obligations. SOKiK refused also the argument that general knowledge (mainly by competitors) of the content of the decision acted as a barrier in fulfilling Carrefour's obligations especially in light of the fact that Carrefour did not apply for secrecy of the decision. Even if, however, secrecy was requested, it would have been justified only in light of very important reasons because - in SOKiK's view - transparency is a key idea of the Competition Act.

\section{Fines}

In a judgment of 21 April 2011, VI Aca 996/10 PZPN/Canal+ ${ }^{46}$, the Court of Appeals criticized SOKiK's positions on two facts which, according to the first instance court, should have been seen by the UOKiK President as mitigating factors in calculating the amount of fines imposed for an antitrust infringement. The first mitigating factor under consideration was the fact that

${ }^{46}$ More on this judgement see a case comment by T. Bagdziński in the current volume of YARS. 
the infringer fulfils public tasks and that worsening of its financial situation (because of the duty to pay the antitrust fine) would have influenced the accomplishment of these tasks. The Court of Appeals claimed that even if Article 104 of the Competition Act 2000 contained an open list of factors that should be considered while determining the fine amount, fulfilling public tasks cannot be treated as a mitigating factor. Approving such view would lead to unacceptable privileges being granted to entities fulfilling public tasks even if they violate competition rules within their economic activities. The Court of Appeals criticised also SOKiK's use of the infringer's bad financial situation as a mitigating factor in calculating its fine. According to the Court, seeing a bad financial situation as a mitigating factor for the imposition of antitrust fines would mean attributing an unjustifiable competitive advantage to undertakings that are worse adapted to market conditions.

The Court of Appeals ruled once again on the possibility to decrease the amount of a fine imposed by the UOKiK President in a judgment of 21 July 2011, VI Aca 1303/10, RPWiK w Tychach. It stated therein that a fine of $0.1 \%$ of the undertaking's annual income was adequate to the gravity of the infringement committed by a municipal supplier of water and sewage collector since the latter was a professional market participant with considerable business experience that concludes contracts mainly with consumers (weakest market players), so it should have acted with special care in order not to violate the law and infringe customer interests. The Court of Appeals shared SOKiK's view, despite the fact that their opinion can be considered rather controversial, that a fine could be relatively small because the scrutinised practice appeared only locally and had a limited territorial scope. Moreover, the UOKiK President did not receive any customer complaints and the undertaking did not create any barriers for the antitrust proceeding.

\section{Status of files of antitrust proceedings (administrative proceeding) before a competition court}

In a judgment of 8 April 2011, VI Aca 1071/10 Miejskie Przedsiebiorstwo Zieleni $w$ Lublinie, the Court of Appeals referred to a claim that an earlier SOKiK judgment had been based on facts established in antitrust proceedings even if the Polish Code of Civil Procedure does not provide for evidence such as files accumulated in administrative proceedings. The second instance court stated that court proceedings before SOKiK are contradictory in nature where evidence collected in the earlier administrative proceedings is regarded as proofs (the Court of Appeals referred to an SN judgment of 20 September 2005, III SZP 2/05). Even if SOKiK acts as a first instance court, the fact that 
it scrutinizes appeals against antitrust decisions causes the necessity to control the activities of the competition authority in its administrative proceeding. Therefore, all files accumulated in the antitrust procedure are to act as the basis for SOKiK's activity in competition law cases. If SOKiK was not to examine the entire content of these files, this could be considered as failure to analyse the case.

\section{Assessment of the UOKiK President' activities by administrative courts}

In order to get a full overview of Polish jurisprudence in antitrust cases, rulings of administrative courts, mainly regional ones cannot be overlooked. The Regional Administrative Court in Warsaw (in Polish: Wojewódzki Saqd Administracyjny; hereafter, WSA) issued in 2011 a number of orders rejecting complaints about the activities as well as non-activity of the UOKiK President. The rejected claims concerned: 1) an order issued by the UOKiK President refusing to grant the status of a procedural party to a non-governmental organization (VI SA-WA 1867/09); 2) lack of information on the result of explanatory proceedings initiated in response to a complaint on an alleged competition law infringement submitted to the UOKiK President (VI SA Wa $1131 / 11)^{47}$; 3) a letter from the UOKiK President stating that the authority, after completing explanatory proceedings, does not intend to initiate a full antitrust procedure (e .g. WSA order of 9 March 2011, VII SA/WA47/11; WSA in Warsaw order of 3 June 2011, VII SA/WA9/11). The Court stated in all those cases that administrative courts are not competent to deal with issues regulated by the Competition Act, mainly because of the features of antitrust proceedings being a 'special' administrative procedure (whereby SOKiK rules on complaints and appeals from the decisions of the UOKiK President). Regarding the letters from the UOKiK President, the Court claimed that they are no more than a piece of information on how the authority dealt with a given case (issue) and thus, they are not subject to (administrative) judicial review $^{48}$.

47 A cassation from this order was rejected by the Supreme Administrative Court by order of 12 July 2011, II GSK 1035/11.

48 The problem of the division of competences between civil and administrative courts is scrutinized by M. Błachucki, 'Właściwość sądów administracyjnych i sądów powszechnych w sprawach antymonopolowych' ['Jurisdiction of administrative courts and civil courts in antitrust cases'] in: M. Błachucki, T. Górzyńska (eds.), Aktualne problemy rozgraniczenia wtaściwości sądów administracyjnych i powszechnych [Current problems of delimitating jurisdiction of administrative and civil courts], Naczelny Sąd Administracyjny, Warszawa 2011, pp. 130-158. 


\section{Application of Article 5 of Regulation 1/2003 by a national competition authority}

In a judgment of 8 June 2011, III SK 2/09, the Supreme Court annulled a judgement of the Court of Appeals (judgment of 10 July 2008, VI ACa $8 / 08$ ) sustaining a SOKiK ruling which questioned a decision delivered by the UOKiK President on the discontinuation of antitrust proceedings concerning an infringement of Article 102 TFEU (previously Article 82 TEC) in relation to Article 5 of Regulation 1/2003. On the issue of a violation of the abuse prohibition on the basis of domestic law, the UOKiK President adopted a decision that no violation of the prohibition took place. Even if the final result of the decision based on EU law and the decision based on domestic law was the same (the undertaking was not declared to have abused its dominant position) the legal basis for the two decisions was different. The UOKiK President decided that a national competition authority (hereafter, NCA) had no power to adopt - on the basis of Article 5 Regulation 1/2003 - a decision declaring that a given practice did not violate the prohibition contained in Article 102 TFEU. In order to rule on the appeal against the resulting judgment of the Court of Appeals, the Supreme Court submitted preliminary questions to the Court of Justice about the competences of NCAs in this respects. Following the judgment of the Court of Justice of 3 May 2011, C-375/0949, the Polish Supreme Court ruled that the UOKiK President did not have the competence to declare that a given undertaking had not committed an Article102 TFEU infringement. Still, the Court did not agree with the entirety of the NCA's reasoning. It claimed that the key of this situation was not the lack of merit of the given proceedings, but the fact that issuing a decision on the non-violation of the Article 102 TFEU prohibition belonged to the exclusive competences of the Commission, even if the actual proceedings were conducted by an NCA. Article 5 tiret 3 of Regulation 1/2003 should be applied directly, so if an NCA determines that the conditions of Article 102 TFEU are not met, it should decide that it has no grounds to act.

49 More on the preliminary judgment of the Court of Justice: K. Kowalik-Bańczyk, 'Jednolite stosowanie unijnego prawa konkurencji jako ograniczenie dla autonomii proceduralnej krajowych organów ochrony konkurencji - glosa do wyroku TS z dnia 3.05.2011 r. w sprawie C-375/09 Prezes UOKiK v. Tele 2 (obecnie Netia)' ['Uniform application of EU competition law as a restriction of the procedural autonomy of national competition protection authorities commentary about CoJ judgment of 3 May 2011 in case C-375/09 Prezes UOKiKv. Tele 2 (now Netia)'] (2012) 2 Europejski Przeglad Sadowy 39-45; I. Szwedziak, 'Is the parallel competence set out in Regulation 1/2003 totally clear? Case comment to the preliminary ruling of the Court of Justice of 3 May 2011 Tele $2 v$ President of Office of Competition and Consumer Protection (Case C-375/09)' (2012) 5(7) YARS. 


\section{Literature}

Błachucki M., 'Właściwość sądów administracyjnych i sądów powszechnych w sprawach antymonopolowych' ['Jurisdiction of administrative courts and civil courts in antitrust cases'] in: M. Błachucki, T. Górzyńska (eds.), Aktualne problemy rozgraniczenia wtaściwości sqdów administracyjnych i powszechnych [Current problems of delimitating jurisdiction of administrative and civil courts], Naczelny Sąd Administracyjny, Warszawa 2011, pp. 130-158.

Błachucki M., R. Stankiewicz, 'Decyzja zezwalająca na dokonanie koncentracji z naruszeniem testu istotnego ograniczenia konkurencji (art. 20 ust. 2 ustawy antymonopolowej)' ['Decision of the competition authority clearing a merger which substantially impedes competition (Art. 20(2) of the Polish antimonopoly act)'] (2010) 6 Przeglad Ustawodawstwa Gospodarczego.

Bolecki A., 'Ustalanie minimalnych cen odsprzedaży - czas na zmiany. Glosa do wyroku Sądu Najwyższego z dnia 23.11.2011 r. w sprawie III SK 21/11 (Röben Ceramika Budowlana)' ['Resale price maintenance - time for changes. Case comment to the judgment of the Supreme Court of 23 November 2011 in case III SK 21/11 (Röben Ceramika Budowlana)'] (2012) 3(1) iKAR.

Brzezińska-Rawa A., 'Nadużycie pozycji dominującej w postaci stosowania ceny nadmiernie wygórowanej' ['Abuse of a dominant position by applying excessive prices'] (2011) 1 Przeglad Prawa Publicznego.

Kowalik-Bańczyk K., 'Jednolite stosowanie unijnego prawa konkurencji jako ograniczenie dla autonomii proceduralnej krajowych organów ochrony konkurencji - glosa do wyroku TS z dnia 3.05.2011 r. w sprawie C-375/09 Prezes UOKiK v. Tele 2 (obecnie Netia)' ['Uniform application of EU competition law as a restriction of the procedural autonomy of national competition protection authorities - commentary about CoJ judgment of 3 May 2011 in case C-375/09 Prezes UOKiK v. Tele 2 (now Netia)'] (2012) 2 Europejski Przeglad Sadowy.

Materna G., 'Wpływ prawa UE na polskie wyłączenia grupowe spod zakazu porozumień ograniczających konkurencje' ['The impact of EU law on Polish block exemption from the prohibition of agreements restricting competition'] (2010) 5 Europejski Przeglad Sadowy.

Orlicka J., 'Wyłączenie grupowe dla porozumień standardowych warunków ubezpieczenia - stan obecny i postulaty de lege ferenda' ['Block exemption for agreements on standard insurance contracts - a current state and de lege ferenda proposals'] (2010) 2(9) Rozprawy Ubezpieczeniowe.

Węgrzynowski Ł., 'Ekwiwalentność świadczeń w orzecznictwie antymonopolowym' ['Equality of subjects of contracts in antitrust jurisprudence'] (2010) 4 Glosa.

Wojtczak E., 'Zwalczanie zmów przetargowych w Polsce' ['Counterfighting tender collusions in Poland'] (2010) 7 Państwo i Prawo. 